\title{
Pengaruh Radiasi Microwave dan Perlakuan Asam pada Batubara Peringkat Rendah terhadap Perolehan Biosolubilisasi Menggunakan Neurospora intermedia
}

\author{
Nendry N. Solihah ${ }^{1}$, Dwiwahju Sasongko ${ }^{2}$, Elvi Restiawaty ${ }^{3,4^{*}}$ \\ ${ }^{1}$ Program Studi Magister Teknik Kimia, Fakultas Teknologi Industri, Institut Teknologi Bandung, Jalan Ganesa 10, \\ Bandung 40132, Indonesia \\ ${ }^{2}$ Kelompok Keahlian Energi dan Sistem Pemrosesan Teknik Kimia, Fakultas Teknologi Industri, Institut Teknologi \\ Bandung, Jalan Ganesa 10, Bandung 40132, Indonesia \\ ${ }^{3}$ Kelompok Keahlian Perancangan dan Pengembangan Proses Teknik Kimia, Fakultas Teknologi Industri, Institut \\ Teknologi Bandung, Jalan Ganesa 10, Bandung 40132, Indonesia \\ ${ }^{4}$ Pusat Penelitian Biosains dan Bioteknologi, Institut Teknologi Bandung, Jalan Ganesa 10, Bandung 40132, Indonesia \\ *email: erestiawaty@che.itb.ac.id
}

\begin{abstract}
Abstrak. Biosolubilisasi batubara peringkat rendah merupakan teknologi yang menjanjikan untuk mendapatkan bahan bakar cair yang ramah lingkungan. Biosolubilisasi batubara peringkat rendah dapat dilakukan dengan menggunakan mikroorganisme seperti Neurospora intermedia yang mampu menghasilkan enzim-enzim pensolubilisasi. Mekanisme biosolubilisasi batubara terjadi karena adsorpsi enzim-enzim tersebut ke permukaan partikel batubara, sehingga proses perlakuan awal batubara perlu dilakukan untuk memudahkan proses adsorpsi enzim. Penelitian ini dilakukan untuk mengkaji pengaruh perlakuan awal partikel batubara peringkat rendah terhadap struktur batubara dan perolehan biosolubilisasi. Pengaruh perlakuan awal tersebut dikaji dengan membandingkan biosolubilisasi menggunakan partikel batubara tanpa perlakuan awal (B1), perlakuan fisik dengan memberikan radiasi microwave 511 Watt selama 5 menit (B2), perlakuan kimiawi dengan merendam partikel batubara dalam $\mathrm{HNO}_{3} 8 \mathrm{M}$ selama 48 jam (B3), serta perlakuan kombinasi radiasi microwave selama 5 menit dan $\mathrm{HNO}_{3}$ dengan konsentrasi 2, 4, 6, dan 8 M selama 48 jam (B4, B5, B6, dan B7). Partikel batubara B1 memiliki rentang diameter mesopori sebesar 33,97 A, sedangkan partikel batubara yang telah mengalami perlakuan awal mengalami peningkatan diameter pori namun masih dalam rentang mesopori. Luas permukaan persatuan massa dan volume pori yang tertinggi diperoleh dari perlakuan B3, masing-masing adalah $44,39 \mathrm{~m}^{2} / \mathrm{g}$ dan 0,09 cc/g. Hasil analisis proksimat dan ultimat menunjukkan bahwa perlakuan asam dapat mengurangi kandungan karbon terikat. Secara kualitatif dapat terlihat bahwa biosolubilisasi batubara B1, B2, B4, dan B5 tidak terjadi dengan baik, sehingga tidak terdapat cairan hitam sebagai hasil batubara yang tersolubilisasi, sedangkan biosolubilisasi batubara B3, B6, dan B7 menghasilkan cairan hitam sejak hari pertama. Secara kuantitatif, biosolubilisasi batubara peringkat rendah menggunakan perlakuan B3 menghasilkan konsentrasi asam humat dan persentase biosolubilisasi yang tertinggi, masing-masing yaitu 186,1 mmol/L dan 67,8\%.
\end{abstract}

Kata kunci: biosolubilisasi batubara, $\mathrm{HNO}_{3}$, Neurospora intermedia, radiasi microwave.

Abstract. Effect of Microwave Radiation and Acid Treatment on Low Grade Coal on Biosolubilization Acquisition Using Neurospora intermedia. Bio-solubilization of low rank coal is a promising technology to obtain environmentally friendly liquid fuel. Bio-solubilization can be carried out using microorganism, such as Neurospora intermedia, which is capable to produce solubilizing enzymes. Mechanism of coal bio-solubilization occurs due to enzymes adsorption onto surface of coal, so that the low rank coal pre-treatment is needed to easy enzyme adsorption. This research examines the effects of low rank coal pre-treatment towards coal structure and bio-solubilization yields. The effects of the pre-treatment were studied by comparing the bio-solubilization using coal with the following specification: without treatment (B1), physical pre-treatment of 511 Watt microwave radiation for 5 minutes (B2), chemical pre-treatment using $8 \mathrm{M} \mathrm{HNO}_{3}$ for 48 hours (B3), and pre-treatment with a combination of microwave radiation for 5 minutes and acid treatment using various $\mathrm{HNO}_{3}$ concentration of 2, 4, 6, and $8 \mathrm{M}$ for 48 hours (B4, B5, B6, and B7, respectively). Coal particle of $B 1$ had mesopore diameter range of $33.97 \AA$, while coal particle with pre-treatment have increased pore diameter, but are still in range of mesopore. The coal obtained by $B 3$ process has the highest specific surface area and pore volume, which were $44.39 \mathrm{~m}^{2} / \mathrm{g}$ and $0.99 \mathrm{cc} / \mathrm{g}$, respectively. The proximate and ultimate analyses showed that acid treatment reduced fixed carbon contain. Coal bio-solubilization of B1, B2, B4, and B5 by qualitative could not be solubilized and there was no black liquid as a result of solubilized coal, meanwhile, B3, B6, and B7 were solubilized easily since the first day. Bio-solubilization of chemically pre-treatment low rank coal, B3, resulted in the highest humic acid concentration and bio-solubilization percentage i.e. $186.1 \mathrm{mmol} / \mathrm{L}$ and $67.8 \%$, respectively.

Keywords: coal bio-solubilization, $\mathrm{HNO}_{3}$, microwave radiation, Neurospora intermedia. 


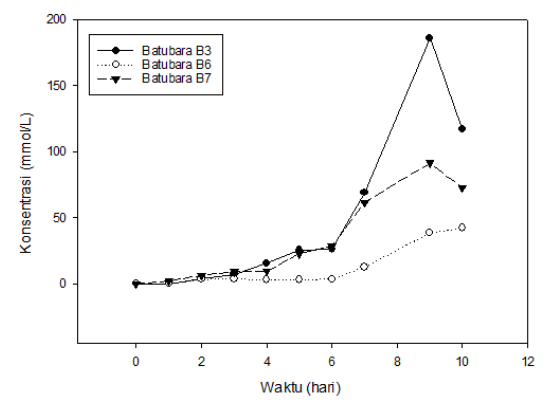

\section{Pendahuluan}

Indonesia memiliki sumber daya batubara sebanyak 166 miliar ton dengan cadangan sebanyak 37 miliar ton (KESDM, 2018). Sebagian besar batubara Indonesia tergolong batubara peringkat rendah sehingga memerlukan teknologi pemrosesan untuk mengubah batubara peringkat rendah menjadi bahan bakar yang benilai kalor tinggi dan ramah lingkungan. Salah satu teknologi yang diajukan adalah teknologi pencairan batubara yang dapat dilakukan secara termal atau biologis. Proses pencairan batubara secara termal dapat dilakukan melalui rute langsung seperti proses NEDO (New Energy Development Organization) yang dikembangkan di Jepang atau rute tidak langsung melalui gasifikasi seperti proses SASOL (South Africa Synthetic Oil Liquefaction). Berbeda dengan pencairan secara termal yang sudah diimplementasikan secara komersial, proses pencairan batubara secara biologis menggunakan mikroorganisme yang disebut biosolubilisasi masih pada tahap penelitian di laboratorium.

Biosolubilisasi batubara menggunakan jamur Polyporus versicolor dan Poria monticola telah diteliti oleh Cohen dan Gabriele (1982). Kedua fungi tersebut tumbuh pada media Sabouraud maltose agar yang di dalamnya terdapat batubara lignit. Cairan hitam yang terbentuk mengindikasikan telah terjadi solubilisasi batubara oleh kedua fungi tersebut. Biosolubilisasi batubara menggunakan $P$. versicolor dilakukan secara enzimatis karena jamur tersebut menghasilkan enzim polyphenoloxidase, peroxidase, dan cellobiose. Berbeda dengan $P$. versicolor, biosolubilisasi batubara menggunakan $P$. monticola terjadi secara non-enzimatis melalui produksi radikal bebas (Cohen dan Gabriele, 1982).

Lebih lanjut, Laborda dkk. (1999) menerangkan proses enzimatis yang terjadi dalam biosolubilisasi batubara. Enzim-enzim yang disekresi oleh mikroba dapat memutus struktur dan ikatan molekul batubara pada tekanan atmosfir dan suhu ruang.

Biosolubilisasi batubara secara enzimatis dipengaruhi oleh beberapa faktor diantaranya ukuran partikel dan jenis batubara (Wadhwa dan Sharma, 1998), perlakuan awal batubara (Tao dkk., 2009), jenis mikroorganisme (Basaran dkk., 2003; Selvi dkk., 2009), jenis media biosolubilisasi (Hölker dkk., 2002), kondisi operasi (Wadhwa dan Sharma, 1998), sumber karbon atau nitrogen serta konsentrasinya (Silva- Stenico dkk., 2007).
Biosolubilisasi batubara secara enzimatis sangat bergantung pada keberhasilan penempelan enzim-enzim ke permukaan partikel batubara. Hal ini karena batubara merupakan bahan yang bersifat hidrofobik sehingga enzim-enzim biosolubilisasi akan sulit teradsorpsi (Yin dkk., 2009; Sugoro dkk., 2012; Zimmermann dan Niemann-Delius, 2007). Untuk itu, penelitian mengenai proses perlakuan awal batubara peringkat rendah yang dapat mengubah karakteristik permukaan batubara sangat diperlukan.

Tao dkk. (2009) melakukan penelitian tentang pengaruh perlakuan awal batubara terhadap produksi enzim-enzim biosolubilisasi yang disekresi oleh jamur pelapuk putih Trichoderma sp. AH. Hasil penelitian menunjukkan bahwa batubara lignit yang telah mendapatkan perlakuan asam nitrat $\left(\mathrm{HNO}_{3}\right) 8 \mathrm{M}$ dapat disolubilisasi dan jumlah enzim-enzim ekstraseluler yang dihasilkan berkolerasi dengan hasil biosolubilisasi. Hasil biosolubilisasi diuji secara kualitatif yang ditunjukkan dengan pembentukan cairan hitam.

Makalah ini melaporkan hasil eksperimen untuk mengamati pengaruh radiasi microwave dan perlakuan asam pada berbagai konsentrasi $\mathrm{HNO}_{3}$ terhadap perolehan produk biosolubilisasi menggunakan jamur Neurospora intermedia.

\section{Metodologi}

\subsection{Inokulasi Neurospora intermedia}

$N$. intermedia merupakan jamur yang diisolasi dari makanan fementasi tradisional Indonesia, yang dikenal sebagai oncom (Restiawaty dkk., 2018). Jamur diaktifkan pada media agar Vogel dalam tabung reaksi selama 5 hari pada suhu ruang dan tekanan atmosfir.

\subsection{Perlakuan awal batubara}

Partikel batubara yang digunakan merupakan batubara lignit berasal dari Pusat Penelitian dan Pengembangan Teknologi Mineral dan Batubara (Puslitbang tekMIRA) dengan diameter 1,5-2,5 mm. Umpan partikel batubara dikelompokkan menjadi: (i) partikel batubara tanpa perlakuan awal, (ii) partikel batubara dengan radiasi oven microwave 511 Watt selama 5 menit, (iii) partikel batubara yang direndam dalam $\mathrm{HNO}_{3} 8 \mathrm{M}$ selama 48 jam, dan (iv) partikel batubara yang diberikan perlakuan awal kombinasi radiasi oven microwave selama 5 menit kemudian direndam dalam $\mathrm{HNO}_{3}$ dengan konsentrasi 2, 4, 6, dan $8 \mathrm{M}$ selama 48 jam (B4, B5, B6, dan B7). Tabel 1 menunjukkan kode umpan 
batubara serta perlakuan yang diberikan terhadap batubara tersebut.

Karakterisasi umpan meliputi analisis $\mathrm{N}_{2}$ adsorpsidesorpsi, analisis proksimat, dan analisis ultimat. Analisis $\mathrm{N}_{2}$ adsorpsi-desorpsi menggunakan metode $\mathrm{BJH}$ (Barret-Joyner-Halenda), dilakukan di laboratorium Instrumentasi dan Analisis, Prodi Teknik Kimia ITB. Sedangkan analisis proksimat dan ultimat dilakukan di laboratorium Pusat Sumber Daya Mineral, Batubara, dan Panas Bumi (PSDMBP), Kementerian ESDM, Bandung.

\subsection{Proses biosolubilisasi batubara}

$N$. intermedia yang telah diinokulasi dalam cawan petri ditambahkan $0,5 \mathrm{~g}$ partikel batubara steril yang telah mengalami perlakuan awal dan diinokulasi kembali selama 10 hari. Pengambilan sampel batubara yang tercairkan dilakukan setiap 24 jam. Partikel batubara yang tidak tersolubilisasi dipisahkan dari spora $N$. intermedia melalui sentrifugasi kemudian dikeringkan pada oven $60^{\circ} \mathrm{C}$ selama 24 jam. Partikel batubara yang telah dikeringkan ditimbang dan dikarakterisasi dengan analisis proksimat. Analisis proksimat batubara sebelum dan setelah proses biosolubilisasi dilakukan untuk mengetahui jumlah batubara yang terkonversi menjadi batubara cair. Jumlah ini dinyatakan dalam persen biosolubilisasi yang dihitung seperti pada persamaan (1), dengan asumsi kandungan abu tetap.

$\%$ biosolubilisasi $=[($ massa awal - massa akhir $) /$ massa akhir] x 100\%

Keterangan persamaan (1): Massa awal = Massa awal karbon terikat dan bahan volatil; Massa akhir = Massa akhir karbon terikat dan bahan volatil.

Tabel 1. Variasi perlakuan awal batubara

\begin{tabular}{ccc}
\hline $\begin{array}{c}\text { Kode umpan } \\
\text { batubara }\end{array}$ & $\begin{array}{c}\text { Radiasi } \\
\text { microwave } 5 \\
\text { menit }\end{array}$ & $\begin{array}{c}\text { Konsentrasi } \\
\mathrm{HNO}_{3}, 48 \text { jam }\end{array}$ \\
\hline B1 & - & - \\
B2 & $\sqrt{ }$ & - \\
B3 & - & $8 \mathrm{M}$ \\
B4 & $\sqrt{ }$ & $2 \mathrm{M}$ \\
B5 & $\sqrt{ }$ & $4 \mathrm{M}$ \\
B6 & $\sqrt{ }$ & $6 \mathrm{M}$ \\
B7 & $\sqrt{ }$ & $8 \mathrm{M}$ \\
\hline
\end{tabular}

Tabel 2. Hasil analisis $\mathrm{N}_{2}$ adsorpsi-desorpsi

\begin{tabular}{ccccc}
\hline $\begin{array}{c}\text { Kode } \\
\text { batubara }\end{array}$ & $\begin{array}{c}\text { SSA BJH } \\
\left(\mathrm{m}^{2} / \mathrm{g}\right)\end{array}$ & $\begin{array}{c}\text { Volume } \\
\text { pori } \\
\text { BJH }(\mathrm{cc} / \mathrm{g})\end{array}$ & $\begin{array}{c}\text { Diameter } \\
\text { pori } \\
\mathrm{BJH}(\AA)\end{array}$ & $\begin{array}{c}\text { Klasifikasi } \\
\text { pori }\end{array}$ \\
\hline B1 & 16,678 & 0,044 & 33,971 & Mesopori \\
B2 & 23,443 & 0,051 & 41,546 & Mesopori \\
B3 & 44,393 & 0,090 & 35,733 & Mesopori \\
B4 & 8,798 & 0,022 & 36,388 & Mesopori \\
B5 & 9,807 & 0,023 & 36,403 & Mesopori \\
B6 & 41,195 & 0,089 & 35,960 & Mesopori \\
B7 & 38,652 & 0,085 & 36,506 & Mesopori \\
\hline
\end{tabular}

Tingkat ketercairan batubara diperkirakan dari kandungan asam humat dan asam fulvat yang diukur melalui spektrofotometri UV-Vis pada panjang gelombang $450 \mathrm{~nm}$ dan $280 \mathrm{~nm}$ (Hala dan Fauzan, 2015; Jannah, 2010; Sekhohola, 2013; Sugoro dkk., 2010; Tao dkk., 2009). Panjang gelombang $450 \mathrm{~nm}$ digunakan untuk mengukur adanya ikatan terkonjungsi pada senyawa aromatik batubara sedangkan panjang gelombang $280 \mathrm{~nm}$ berfungsi untuk mengukur adanya senyawa fenolik. Asam humat dan asam fulvat merupakan salah satu indikator terjadinya proses biosolubilisasi batubara. Keduanya terdapat di dalam batubara dan dilepaskan selama proses biosolubilisasi batubara berlangsung. Analisis spektrofotometri UV-Vis digunakan juga sebagai salah satu metode untuk menghitung laju biosolubilisasi batubara. Pengukuran kandungan ikatan terkonjungsi menggunakan senyawa asam humat murni sebagai senyawa standar, namun untuk pengukuran senyawa fenolik tidak menggunakan senyawa standar/blanko.

\section{Hasil dan Pembahasan}

\subsection{Analisis $\mathrm{N}_{2}$ adsorpsi-desorpsi}

Partikel batubara yang telah mengalami perlakuan awal dilakukan analisis $\mathrm{N}_{2}$ adsorpsi-desorpsi dengan hasil seperti pada Tabel 2. Partikel batubara B1 memiliki luas permukaan persatuan massa (SSA) yang lebih kecil dibandingkan partikel batubara B2, sama halnya dengan volume dan diameter pori $(\mathrm{B} 2>\mathrm{B} 1)$. Perubahan ini terjadi karena proses radiasi microwave menyebabkan pengurangan kandungan bahan volatil yang dilepaskan dalam bentuk gas. Pelepasan gas ini menyebabkan fraktur dalam batubara (Marland dkk., 2000). Selain itu, Zimmerman dan Niemann-Delius (2007) memaparkan bahwa kandungan air dalam batubara memiliki sifat dielektrik dan merupakan penyerap energi yang baik. Ketika kandungan air dalam batubara terpapar radiasi microwave, yang merupakan medan listrik bolak-balik, molekul menyesuaikan diri searah bidang dengan frekwensi yang sama. Gerakan yang cepat ini menghasilkan gesekan antarmolekul, sehingga menyebabkan kenaikan suhu. Jika waktu pemaparan cukup, air dalam batubara akan menguap dan mengembang. Proses ini menciptakan kenaikan tekanan internal pada partikel batubara kemudian menghasilkan fraktur dan uap air yang dihasilkan menguap.

Partikel batubara yang direndam dalam $\mathrm{HNO}_{3} 8 \mathrm{M}$ menyebabkan terjadinya proses oksidasi. Proses oksidasi mengakibatkan perubahan pada gugus fungsi batubara menjadi lebih hidrofilik dan meningkatkan tempat adsorpsi enzim ke dalam batubara (Sugoro dkk., 2012). Perubahan gugus fungsi batubara tersebut terlihat dari hasil analisis FTIR yang dilakukan oleh beberapa peneliti sebelumnya seperti Machnikowska dkk. (2002), Alvarez dkk. (2003), dan Yin dkk. (2009). Hasil analisis FTIR menunjukan peningkatan pada panjang gelombang 3500 $3100 \mathrm{~cm}^{-1}$ yang merupakan gugus karbonil, karboksil dan eter, gugus tersebut merupakan tempat adsorpsi enzim. Selain itu, proses oksidasi mengakibatkan peningkatan nilai SSA, volume, dan diameter pori (B3>B1). Peningkatan nilai SSA mengindikasikan akan terjadi 
penambahan jumlah interaksi permukaan partikel batubara dengan enzim.

Partikel batubara B4 dan B5 memberikan hasil bahwa nilai SSA dan volume pori menurun dibandingkan dengan batubara tanpa perlakuan awal (B4 dan B5 < B1), sedangkan nilai diameter pori meningkat. Radiasi oven microwave mengakibatkan terbentuknya fraktur pada batubara sehingga diameter batubara B4 dan B5 menjadi lebih besar. Batubara yang telah menghasilkan fraktur ini direndam dalam $\mathrm{HNO}_{3}$ dengan konsentrasi $2 \mathrm{M}$ dan $4 \mathrm{M}$. Proses oksidasi $\mathrm{HNO}_{3}$ dengan konsentrasi rendah menyebabkan beberapa pori tersumbat oleh gugus oksida yang dihasilkan sehingga SSA dan volume pori B4 dan B5 menurun (Shim dkk., 2001).

Hasil perlakuan awal partikel batubara B6 dan B7 mengalami peningkatan nilai SSA, volume, dan diameter pori dibandingkan dengan batubara tanpa perlakuan awal (B6 dan B7 > B1). Namun, jika dibandingkan dengan partikel batubara B3 nilai SSA dan volume pori lebih kecil, sedangkan diameter lebih besar. Hal ini karena partikel batubara B3, yang masih memiliki kandungan air, lebih mudah dioksidasi oleh $\mathrm{HNO}_{3}$, sedangkan kandungan air partikel batubara B6 dan B7 telah berkurang akibat radiasi microwave. Diameter pori batubara B6 dan B7 lebih besar dari pada B3 karena terdapat fraktur yang dihasilkan pada proses radiasi oven microwave.

\subsection{Analisis proksimat dan ultimat batubara}

Analisis proksimat dan ultimat dilakukan pada partikel batubara B1, B2, B3, B6, dan B7, sedangkan partikel batubara B4 dan B5 tidak dilakukan analisis. Analisis proksimat pada partikel batubara B2 menunjukan penurunan kandungan air, sebagai akibat dari radiasi microwave. Kandungan abu dalam batubara B2 dan B7 tidak banyak mengalami perubahan. Hasil yang sama didapatkan pada penelitian yang dilakukan oleh Marland dkk (2000). Sedangkan kandungan abu pada batubara B3 mengalami penurunan yang cukup tinggi, sama halnya dengan hasil penelitian yang dilakukan oleh Alvarez dkk (2003). Hasil analisis proksimat batubara disajikan pada Tabel 3 .

Hasil analisis ultimat menunjukan penurunan kandungan $\mathrm{C}, \mathrm{H}$, dan $\mathrm{S}$ pada partikel batubara B3, B6, dan B7. Penurunan ini terjxadi karena reaksi oksidasi dengan $\mathrm{HNO}_{3}$ yang menghasilkan gas $\mathrm{CO}_{2}, \mathrm{H}_{2} \mathrm{O}, \mathrm{CO}$, $\mathrm{C}_{\mathrm{x}} \mathrm{H}_{\mathrm{y}}$, dan $\mathrm{H}_{2}$ dan terjadinya proses desulfurisasi (Alvarez dkk., 2003; Elbeyli dan Piskin, 2004).

Tabel 3. Analisis proksimat batubara hasil perlakuan awal

\begin{tabular}{ccccc}
\hline $\begin{array}{c}\text { Kode } \\
\text { batubara }\end{array}$ & $\begin{array}{c}\text { Kadar air } \\
(\% \text { adb })\end{array}$ & $\begin{array}{c}\text { Abu } \\
(\% \text { adb })\end{array}$ & $\begin{array}{c}\text { Bahan } \\
\text { volatil } \\
(\% \text { adb })\end{array}$ & $\begin{array}{c}\text { Karbon } \\
\text { terikat } \\
(\% \text { adb })\end{array}$ \\
\hline B1 & 16,76 & 5,87 & 39,23 & 38,14 \\
B2 & 12,53 & 5,44 & 43,21 & 38,82 \\
B3 & 12,11 & 3,96 & 51,83 & 32,10 \\
B6 & 17,85 & 3,34 & 48,94 & 30,79 \\
B7 & 11,86 & 5,59 & 52,16 & 30,39 \\
\hline
\end{tabular}

Tabel 4. Analisis ultimat batubara hasil perlakuan awal

\begin{tabular}{cccccc}
\hline $\begin{array}{c}\text { Kode } \\
\text { batubara }\end{array}$ & $\begin{array}{c}\mathrm{C} \\
(\% \text { daf })\end{array}$ & $\begin{array}{c}\mathrm{H} \\
(\% \text { daf })\end{array}$ & $\begin{array}{c}\mathrm{N} \\
(\% \text { daf })\end{array}$ & $\begin{array}{c}\mathrm{S} \\
(\% \text { daf })\end{array}$ & $\begin{array}{c}\mathrm{O} \\
(\% \mathrm{daf})\end{array}$ \\
\hline B1 & 67,98 & 4,58 & 1,56 & 0.16 & 25,67 \\
B2 & 68,57 & 4,72 & 1,57 & 0,3 & 24,77 \\
B3 & 58,52 & 3,69 & 5,43 & 0,1 & 32,24 \\
B6 & 58,25 & 3,56 & 5,52 & 0,12 & 32,52 \\
B7 & 58,15 & 3,66 & 5,57 & 0,14 & 32,45 \\
\hline
\end{tabular}

Tabel 5. Persen biosolubilisasi batubara

\begin{tabular}{cccc}
\hline Kode & Hari & \multicolumn{2}{c}{ Persen biosolubilisasi } \\
batubara & ke- & Gravimetri & Persamaan 1 \\
\hline $\begin{array}{c}\text { Residu } \\
\text { Batubara B3 } \\
\text { Residu }\end{array}$ & 9 & $38,7 \%$ & $67,7 \%$ \\
$\begin{array}{c}\text { Batubara B6 } \\
\text { Residu }\end{array}$ & 10 & $29 \%$ & $51,7 \%$ \\
Batubara B7 & 9 & $14,5 \%$ & $45,8 \%$ \\
\hline
\end{tabular}

Partikel batubara B2 mengalami penurunan kandungan $\mathrm{O}$, hal ini karena partikel batubara B2 telah mengalami radiasi microwave. Kandungan $\mathrm{N}$ dan $\mathrm{O}$ pada partikel batubara B3, B6, dan B7 mengalami kenaikan yang cukup tinggi, sebagai akibat dari oksidasi oleh $\mathrm{HNO}_{3}$. Hasil analisis ultimat disajikan pada Tabel 4.

\subsection{Produk biosolubilisasi batubara}

$N$. intermedia dibiakkan pada media agar Vogel dalam cawan petri hingga hari kelima pertumbuhan. Pada hari kelima spora $N$. intermedia telah tumbuh memenuhi seluruh permukaan agar Vogel seperti terlihat pada Gambar 1. Proses biosolubilisasi batubara dilakukan pada hari kelima pertumbuhan karena pada waktu tersebut $N$. intermedia telah memasuki fasa stasioner dan karena produk biosolubilisasi batubara merupakan metabolit sekunder bagi $N$. intermedia (Delvira dan Febriana, 2017). Batubara yang digunakan pada proses biosolubilisasi adalah batubara B3, B6 dan B7. Hal ini karena pada penelitian pendahuluan batubara B1, B2, B4 dan B5 tidak tersolubilisasi oleh $N$. intermedia hingga hari ke-15.

Menurut Tao dkk. (2009) keberadaan batubara menghasilkan enzim-enzim ekstraseluler berupa Lignin Peroksidase (LiP), Mangan Peroksidase (MnP), Fenol oksidase, dan Lakase. Enzim-enzim ini mendegradasi batubara padat menjadi cairan yang mengandung asam humat. Asam humat yang dihasilkan didegradasi lebih lanjut oleh MnP menjadi asam fulvat. Gambar 2, 3, dan 4 merupakan nilai absorbansi produk biosolubilisasi batubara B3, B6 dan B7 pada panjang gelombang 450 $\mathrm{nm}$ dan $280 \mathrm{~nm}$. Kecenderungan dari kedua panjang gelombang memiliki kemiripan namun absorbansi pada panjang gelombang $280 \mathrm{~nm}$ lebih besar dibandingkan $450 \mathrm{~nm}$. Hal ini karena laju pembentukan asam fulvat lebih cepat, sehingga ketika asam humat terbentuk akan didegradasi lebih lanjut menjadi asam fulvat (Yuan dkk., 2006). Analisis spektrofotometri UV-Vis juga digunakan untuk menggambarkan laju biosolubilisasi batubara yang 
terjadi pada masing-masing variasi perlakuan awal batubara.

Untuk ketiga variasi perlakuan awal batubara, pada hari pertama proses biosolubilisasi telah terdapat tetesan cairan hitam dalam jumlah yang masih sedikit. Peningkatan jumlah tetesan cairan hitam terjadi hingga hari kesembilan dan sepuluh, seperti terlihat pada Gambar 2, 3, dan 4. Rendahnya batubara cair yang dihasilkan pada hari-hari awal proses biosolubilisasi karena enzim belum terdistribusi merata ke dalam batubara (Delvira dan Febriana, 2017). Hal lain yang menyebabkan sedikitnya jumlah batubara cair dihari pertama proses biosolubilisasi adalah interaksi antara enzim dengan permukaan batubara terjadi pada dua tingkatan, yaitu adsorpsi fisik dan adsorpsi kimiawi (Manoj dan Elcey, 2010). Pada awal proses biosolubilisasi batubara interaksi yang terjadi adalah adsorpsi fisik. Adsorpsi fisik terjadi karena gaya elektrostatik antara sel mikroba yang bermuatan positif dengan mineral batubara yang bermuatan negatif (Manoj dan Elcey, 2010). Peningkatan batubara cair terjadi pada hari keempat karena pada hari tersebut terjadi adsorpsi kimiawi antara ikatan kimia sel dan mineral batubara. Penurunan terjadi pada hari kesepuluh proses biosolobilisasi. Penurunan ini mengindikasikan produktivitas enzim pada hari kesepuluh proses biosolubilisasi telah menurun.

Produksi asam humat dan asam fulvat pada biosolubilisasi batubara B6 meningkat secara tajam pada hari ketujuh hingga hari kesepuluh, seperti terlihat pada Gambar 3. Hal ini terjadi karena proses adsorpsi fisik antara sel mikroba dengan mineral batubara. Muatan negatif pada batubara dihasilkan dari perubahan gugus fungsi saat proses oksidasi. Proses oksidasi ini bergantung pada konsentrasi oksidator yang digunakan. Proses oksidai $\mathrm{HNO}_{3}$ pada batubara $\mathrm{B} 6$ dengan konsentrasi rendah menyebabkan muatan negatif yang dihasilkan batubara B6 lebih kecil, sehingga adsorpsi fisik enzim lebih lambat. Hal yang berbeda terjadi pada hasil batubara cair B3 dan B7. Proses oksidasi menggunakan $\mathrm{HNO}_{3} 8 \mathrm{M}$ menyebabkan muatan negatif yang dihasilkan lebih banyak sehingga proses adsorpsi fisik lebih cepat. Produksi asam humat dan asam fulvat meningkat pada hari ketiga hingga hari kesembilan, kemudian menurun pada hari kesepuluh. Gambar 5 menunjukan kondisi media agar Vogel pada hari kesepuluh proses biosolubilisasi batubara.

Penentuan konsentrasi asam humat dilakukan dengan menggunakan senyawa standar asam humat murni. Nilai absorbansi pada panjang gelombang $450 \mathrm{~nm}$ dikonversi menjadi konsentrasi asam humat melaui kurva standarisasi. Gambar 6 menunjukan konsentrasi asam humat yang dihasilkan batubara cair B3, B6 dan B7. Batubara B3 menghasilkan konsetrasi asam humat paling besar dibandingkan dengan batubara lainnya yaitu 186,1 $\mathrm{mmol} / \mathrm{L}$, hal ini karena adsorpsi enzim ke dalam batubara terjadi lebih baik dibandingkan batubara perlakuan lainnya. Sedangkan konsentrasi asam humat yang dihasilkan batubara B6 yaitu 42,3 $\mathrm{mmol} / \mathrm{L}$ dan batubara B7 yaitu 91,5 mmol/L. Konsentrasi asam humat yang dihasilkan batubara B7 lebih besar daripada B6 karena pengaruh proses perlakuan awal batubara.

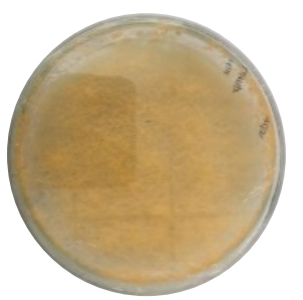

Gambar 1. Pertumbuhan $N$. intermedia dalam media Vogel setelah 5 hari

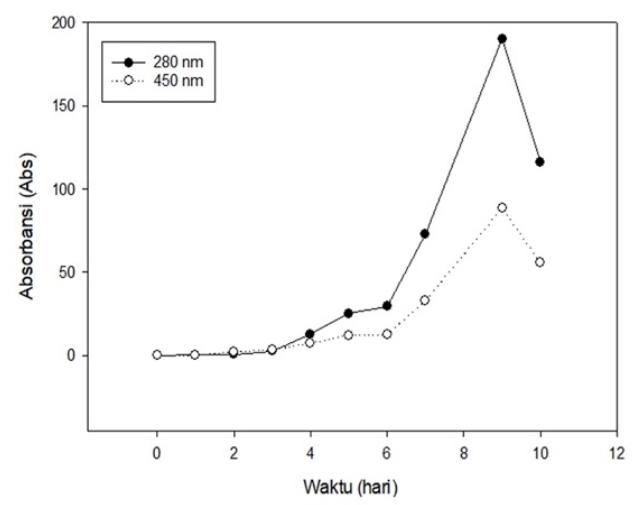

Gambar 2. Absorbansi produk biosolubilisasi batubara B3

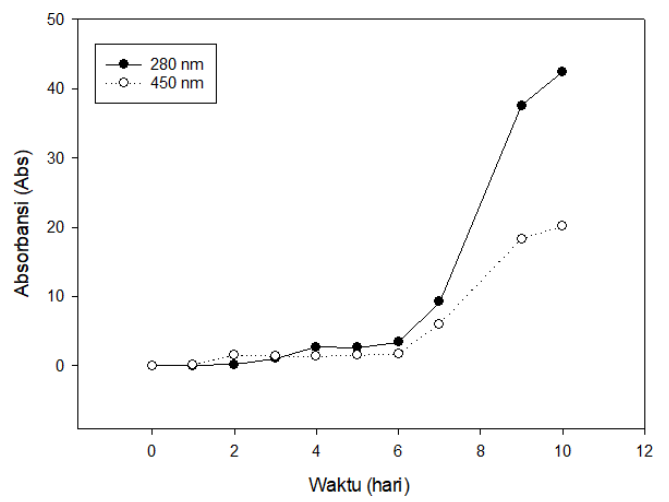

Gambar 3. Absorbansi produk biosolubilisasi batubara B6

\subsection{Persen biosolubilisasi batubara}

Penentuan persen biosolubilisasi batubara dilakukan dengan dua metode, yaitu metode gravimetri dan metode perhitungan hasil analisis proksimat dengan asumsi kandungan abu tetap. Metode gravimetri dilakukan dengan menghitung selisih massa batubara awal dengan massa batubara residu, sedangkan metode perhitungan hasil analisis proksimat seperti pada persamaan (1). Sampel yang digunakan yaitu batubara residu B3 pada hari ke-9, batubara residu B6 pada hari ke-10, dan batubara residu B7 pada hari ke-9. Hal ini dilakukan berdasarkan perolehan asam humat dan asam fulvat tertinggi dari masing-masing variasi. Persen biosolubilisasi batubara disajikan dalam Tabel 5.

Perbedaan hasil persen biosolubilisasi dari kedua metode ini karena parameter yang digunakan berbeda. 
Metode gravimetri meninjau selisih massa batubara awal dengan massa batubara residu. Batubara residu dilakukan sentrifugasi untuk memisahkan spora dari $N$. intermedia yang kemudian dikeringkan, namun pemisahan ini tidak terjadi secara sempurna. Hal ini karena terdapat beberapa spora yang masuk ke dalam pori-pori batubara dan sulit untuk dipisahkan. Akibatnya massa batubara residu menjadi lebih berat dan perolehan persen biosolubilisasi batubara menjadi lebih kecil dibandingkan dengan metode hasil analisis proksimat. Persen biosolubilisasi batubara dengan perhitungan hasil analisis proksimat meninjau kandungan bahan volatil dan karbon terikat yang terkandung dalam batubara. Kandungan bahan volatil dan karbon terikat batubara residu lebih kecil dibandingkan batubara awal. Hal ini karena sebagian kandungan batubara telah terkonversi menjadi cairan.

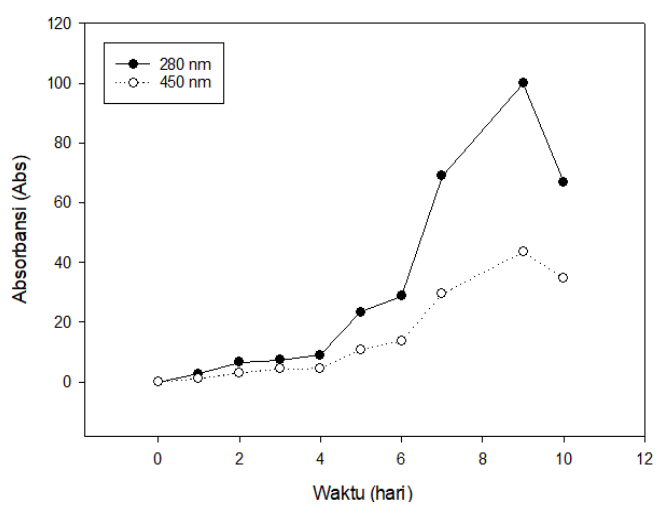

Gambar 4. Absorbansi produk biosolubilisasi batubara B7

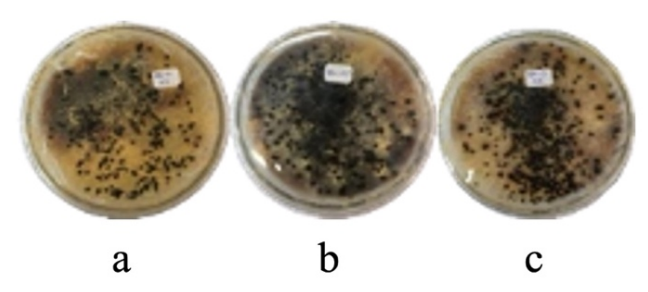

Gambar 5. Proses biosolubilisasi batubara hari kesepuluh pada batubara. (a) B3, (b) B6, (c) B7

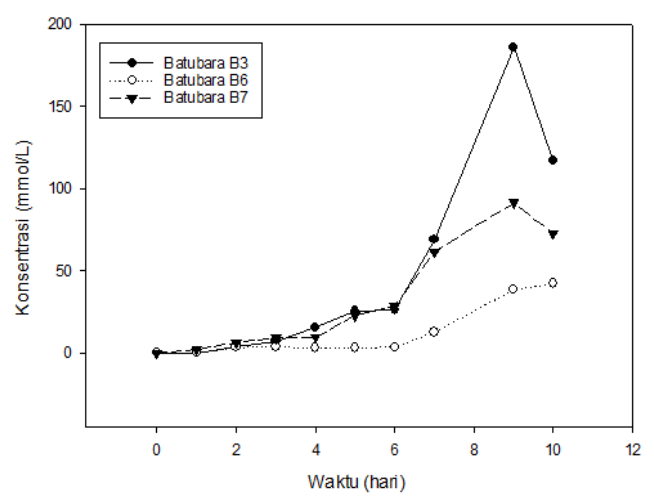

Gambar 6. Konsentrasi asam humat dalam produk biosolubilisasi batubara B3, B6, dan B7

\section{Kesimpulan}

Partikel batubara yang telah diberi perlakuan awal mengalami perubahan struktur dan kandungannya. Hasil analisis $\mathrm{N}_{2}$ adsorpsi-desorpsi menunjukkan terjadi perubahan luas permukaan persatuan massa, volume, dan diameter pori. Selain itu, terdapat perubahan pada kandungan bahan volatil, batubara terikat, kandungan air, dan abu. Konsentrasi $\mathrm{HNO}_{3}$ yang digunakan pada perlakuan awal berpengaruh terhadap luas permukaan persatuan massa, volume, diameter pori, kandungan batubara dan proses biosolubilisasi. Partikel batubara B2, B4, dan B5 tidak dapat tersolubilisasi oleh $N$. intermedia. Sedangkan partikel batubara B3, B6, dan B7 dapat tersolubilisasi pada hari pertama proses.

Partikel batubara B3 menghasilkan produk asam humat tertinggi yaitu $186,1 \mathrm{mmol} / \mathrm{L}$. Sedangkan partikel batubara B6 dan B7 menghasilkan produk asam humat dengan konsentrasi 42,3 dan 91,5 mmol/L. Persen biosolubilisasi batubara B3, B6, dan B7 berdasarkan perhitungan persamaan (1) adalah $67,7 \%, 51,7 \%$, dan $45,8 \%$. Sedangkan persen biosolubilisasi berdasarkan gravimetri untuk batubara B3, B6, dan B7 adalah 38,7\%, $29 \%$, dan $14,5 \%$.

Perlakuan batubara menggunakan radiasi microwave berpengaruh terhadap struktur dn proses biosolubilisasi batubara. Perlakuan menggunakan $\mathrm{HNO}_{3}$ $8 \mathrm{M}$ menghasilkan produk biosolubilisasi batubara lebih baik dibandingkan dengan perlakuan yang ditambahkan radiasi microwave.

\section{Ucapan Terima kasih}

Terima kasih kepada Program Penelitian, Pengabdian kepada Masyarakat, dan Inovasi (P3MI) ITB 2018 yang telah memberikan bantuan dana penelitian.

\section{Daftar Pustaka}

Alvarez, R.; Clemente, C.; Gomez-Limon, D., The Influence of Nitric Acid Oxidation of Low Rank Coal and Its Impact on Coal Structure. Fuel, 2003, 82, 2007-2015.

Başaran, Y.; Denizli, A.; Sakintuna, B.; Taralp, A.; Yurum, Y., Bio-liquefaction/solubilization of Low-Rank Coal Turkish Lignites and Characterization of The Products. Energy and Fuels, 2003, 17, 1068-1074.

Cohen, M.S.; Gabriele, P.D., Degradation of Coal by the Fungi Polyporus versicolor and Poria monticola. Applied and Environmental Microbiology, 1982, 44, 2327.

Delvira, S.; Febriana, K., Effect of Temperature on the Biosolubilization of Low-ranked Coal Using Crude Enzyme from Neurospora sp. Laporan Tugas Akhir Program Sarjana, Institut Teknologi Bandung, Bandung, 2017.

Elbeyli, I.Y.; Pişkin, S., The Effect of Oxidation on The Structure Properties and Calorific Values of Lignites. Sigma, 2004, 4, 43-49. 
Hala, A.F.; Fauzan, R.F.S., Pengaruh Jenis Konsentrasi Sumber Karbon Terhadap Biosolubilisasi Batuubara Subbituminous Oleh Neurospora sp. Laporan Tugas Akhir Program Sarjana, Institut Teknologi Bandung, Bandung, 2015.

Hölker, U.; Schmiers, H.; Grosse, S.; Winkelhöfer, M.; Polsakiewicz, M.; Ludwig, S.; Dohse, J.; Höfer, M., Solubilization of Low-rank Coal by Trichoderma atroviride: Evidence for The Involvement of Hydrolytic and Oxidative Enzymes by Using 14C-Labelled Lignite. Journal of Industrial Microbiology and Biotechnology, 2002, 28, 207-212.

Jannah, M., Karakterisasi Produk Biosolubilsasi Batubara Lignit Oleh Kapang Indigenous dari Tanah Pertambangan Sumatera Selatan, Skripsi Program Sarjana, Universitas Islam Negeri Syarif Hidayatullah, Jakarta, 2010.

Laborda, F.; Monistrol, I.F.; Luna, N.; Fernandez, M., Processes of Liquefaction/Solubilization of Spanish Coals by Microorganisms. Applied Microbiology and Biotechnology, 1999, 52, 49-56.

Machnikowska, H.; Pawelec, K.; Podgórska, A; Microbial Degradation of Low Rank Coals. Fuel Processing Technology, 2002, 77, 17-23.

Marland, S.; Han, B.; Merchant, A.; Rowson, N., The Effect of Microwave Radiation on Coal Grindability. Fuel, 2000, 79, 1283-1288.

Manoj, B.; Elcey, C.D., Demineralization of Coal by Stepwise Bioleaching: A Study of Sub- bituminous Indian Coal by FTIR and SEM. Journal of the University of Chemical Technology and Metallurgy, 2010, 45, 38590 .

Restiawaty, E.; Arina, L.A.; Budhi, Y.W., Development of Bioethanol Production from Sugarcane Bagasse using Neurospora intermedia on Solid State Culture. Asian Journal of Microbiology, Biotechnology \& Environment Sciences, 2018, 20, 98-103.

Sekhohola, L.M.; Igbinigie, E.E.; Cowan, A.K., Biological Degradation and Solubilization of Coal. Biodegradation, 2013, 24, 305-318.

Selvi, A.V.; Banerjee, R.; Ram, L.C.; Singh, G., Biodepolymerization Studies of Low Rank Indian Coals. World Journal of Microbiology and Biotechnology, 2009, 25, 1713-1720.

Shim, J.; Park, S.; Ryu, S., Effect of Modification with $\mathrm{HNO}_{3}$ and $\mathrm{NaOH}$ on Metal Adsorption by Pitch-based Activated Carbon Fibers. Carbon, 2001, 39, 1635-1642.

Silva-Stenico, M.E.; Vengadajellum, C.J.; Janjua, H.A.; Harrison, S.T.; Burton, S.G.; Cowan, D.A., Degradation of Low Rank Coal by Trichoderma atroviride ES11.
Journal of Industrial Microbiology \& Biotechnology, 2007, 34, 625-631.

Sugoro, I.; Hermanto, S.; Indriani. D.; Aditiawati, P.; Sasongko, D., Karakterisasi Produk Biosolubilisasi Batubara oleh kapang T4 Hasil Isolasi dari Tanah Pertambangan Tanjung Enim Sumatera Selatan. Valensi, 2010, 2(1), 325-332.

Sugoro, I.; Astuti, D.I.; Sasongko, D.; Aditiawati, P., Biosolubilisasi Lignit Mentah Hasil Iradiasi Gamma dan oleh Trichoderma asperellum. Jurnal Ilmiah Aplikasi Isotop dan Radiasi, 2012, 8, 51-56.

Tao, X.X.; Pan, L.Y.; Shi, K.Y.; Yin, S.D.; Luo, Z.F., Bio-solubilization of Chinese Lignite I: Extra-cellular Protein Analysis. Mining Science and Technology (China), 2009, 19, 358-362.

Wadhwa, G.; Sharma, D.K., Microbial Pretreatment of Coals: A Tool for Solubilization of Lignite in Organic Solvent-quinoline. World Journal of Microbiology and Biotechnology, 1998, 14, 751-763.

Yin, S.D.; Tao, X.X.; Shi, K.Y., Bio-solubilization of Chinese Lignite II: Protein Adsorption onto The Lignite Surface. Mining Science and Technology (China), 2009, 19, 363-368.

Yuan, H.L.; Yang, J.S.; Wang, F.Q.; Chen, W.X., Degradation and Solubilization of Chinese Lignite by Penicillium sp. P6. Applied Biochemistry and Microbiology, 2006, 42, 52-55.

Zimmermann, E.; Niemann-Delius, C., Microwave Beneficiation of Brown Coal. Górnictwo $i$ Geoinżynieria, 2007, 31, 627-633. 